\title{
Developing methodology for description of biosphere development at Olkiluoto disposal site utilising forest studies at other land uplift sites
}

\author{
A.T.K. Ikonen ${ }^{1}$, L. Aro ${ }^{2}$ and M. Saarinen ${ }^{2}$ \\ ${ }^{1}$ Posiva Oy, 27160 Olkiluoto, Finland \\ ${ }^{2}$ Finnish Forest Research Institute, Parkano Research Station, Kaironiementie 54, \\ 39700 Parkano, Finland
}

\begin{abstract}
In Finland, Olkiluoto Island has been selected as the site for disposal of spent nuclear fuel. When creating biosphere models for the safety assessments, local main features and processes need to be taken into account. Characteristic of the site is land uplift $(6 \mathrm{~mm} / \mathrm{a})$ exposing continuously new land for colonization by plant and animal communities. The forest vegetation succession on these stony, fine-grained till soils starts from deciduous shoreline vegetation and ends in almost pure Norway spruce forests. This has enabled to study processes in soils and forests of different developmental stages, to monitor forest condition and the factors affecting it in other land uplift sites. It has also made possible gradient studies of the succession of boreal mire ecosystems without waiting thousands of years. In this paper, a methodology is described to establish a descriptive model on the development of the biosphere to indicate possible ecosystem distributions and main characteristics on the area on the basis of above-mentioned studies carried out in the area of the Gulf of Bothnia, and of results of the site investigations at Olkiluoto. The description will be used as a basis for selection of appropriate ecosystem modules and parameter values in the subsequent assessment model systems.
\end{abstract}

\section{INTRODUCTION}

In Finland, two companies - Teollisuuden Voima Oy and Fortum Power and Heat Oy - utilise nuclear power (2x840 $\mathrm{MW}_{\mathrm{e}}, 2 \mathrm{x} 490 \mathrm{MW}_{\mathrm{e}}$ ) to generate electricity. In addition, a new $1600-\mathrm{MW}_{\mathrm{e}}$ unit is under construction. Posiva Oy, a company jointly owned by them, is responsible of research and development regarding disposal of spent nuclear fuel and, ultimately, of the construction and operation of the repository itself. In December 2000 the Council of State made and in May 2001 the Finnish Parliament ratified a decision-in-principle for a repository of spent nuclear fuel from the Finnish nuclear power plants (NPP) into the vicinity of the Olkiluoto NPP in western Finland.

The studies for the management of spent nuclear fuel began in Finland in the 1970's. Since then, persistent and thorough investigations have shown that Finnish bedrock provides beneficial conditions to isolate the spent nuclear fuel permanently from the living nature. The site characterisation program for finding and confirming a suitable location for the repository has now been focused into Olkiluoto Island. The next major step of the project is to build a site-specific underground research facility; the excavations started in July 2004. The aim is to begin constructing the actual repository around 2013 and get it in operation in 2020. 


\section{OLKILUOTO SITE}

The Olkiluoto Island $\left(12 \mathrm{~km}^{2}\right)$ is situated on the Finnish coast of the Bothnian Sea (Fig. 1). The coast is characterised by shallow bays surrounded by small archipelagos. The soil of this relatively flat island is mainly stony moraine originating from the bedrock consisting of mostly mica gneiss and other Svecofennian metasediments and plutonic rocks. The landscape in Olkiluoto is characterised by commercial forests, rocky hills, and some nutrient-rich mires and near shore also by meadows and colonies of common reed. The whole local hydrogeochemical and biological system is affected by the postglacial land uplift (6 mm/a) typical to the coastal area in general [1].

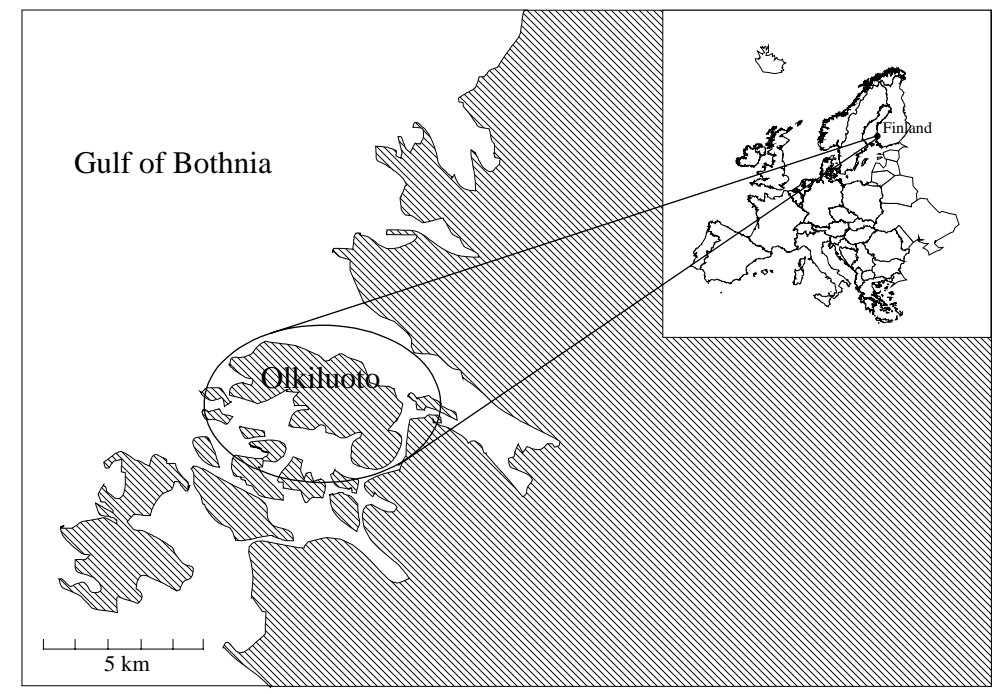

Figure 1. Location of the Olkiluoto Island and its surroundings.

\section{CONTEXTS OF BIOSPHERE ASSESSMENT AND DESCRIPTIONS}

\subsection{Safety assessment context}

The Finnish disposal concept is based on long-term isolation within iron-copper canisters surrounded by bentonite buffer and emplaced in deep crystalline bedrock (about 400-500 meters below ground surface). The regulations (e.g. [2]) set the criteria for the timeframe to be assessed. They emphasise that the repository design need to effectively hinder the release of disposed radioactive substances into the host rock for several thousands of years. For the quantitative safety assessment calculations, the regulatory endpoints for a period up to "at least several thousands of years after the closure of the repository" [2] are shown in Table 1. After that period, in the long term, the quantitative regulatory criteria are based on constraints on the release rate of long-lived radionuclides from the geosphere into the biosphere.

Table 1. The safety assessment endpoints stated in the Finnish regulations [2] for a time period of at least several thousands of years from the closure of the repository.

\begin{tabular}{|l|l|}
\hline Endpoint & Criterion \\
\hline Annual effective dose to the most exposed members of the public & Less than $0.1 \mathrm{mSv}$ \\
\hline Average annual effective dose to the other members of public & Insignificantly low \\
\hline Effects on species of fauna and flora & No detrimental \\
\hline Effects on individuals of domestic animals and rare plants and animals & No detrimental \\
\hline
\end{tabular}


The regulations also give guidance on the potential exposure environments and pathways to be considered. The endpoints for non-human biota should be assessed by using typical exposures and environments for relevant species. The biosphere assessment is to be based on similar type of climate, human habits, nutritional needs and metabolism to the current ones, but to take account reasonably predictable changes in the environment, i.e., at least the land uplift and subsequent emergence of new land area [2].

In general, the next Finnish assessment of the safety of the disposal of spent nuclear fuel will be rather a safety case with extensive scientific support than a traditional quantitative safety assessment. However, the core will still be the quantitative radionuclide migration modelling to demonstrate the compliance to the regulations, requiring also input from the biosphere modelling as dose conversion factors (activity flow to dose rates) for different exposure cases and the probabilities of such cases. In addition, also the biosphere assessment should be based on good-quality science and site data as far as possible taking into account the diversity and complexity of the (surface) environment [3].

\subsection{Modelling scales in the biosphere assessments - need for the development description}

The biosphere as modelled in the safety assessments, comprises of multiple exposure environments with an extent in area and their own ecologically sound characteristics, e.g. sea, wetlands, agriculture land, forests. On the other hand, the safety assessment is basically tracking the behaviour of trace amounts of radioactive molecules, which is modelled based on very small-scale experiments and bold extrapolation. In a modern, well-reasoned assessment, though, different levels of details need to be taken into account at different levels of the biosphere modelling system. For example for a terrestrial system, tracer experiments can usually be carried out in a scale of a soil column or more seldom for a single stand. In the biosphere assessments modelling a catchment is, in most cases, practically too small unit and, on the other hand, needs to be broken into smaller "ecosystem modules" to be chained to represent a catchment and further a site (see e.g. [4]).

In addition to mere models, one needs to parameterise them and assign representative parameter values based on site-specific studies wherever reasonable and possible. Because of resource limitations, it is usually possible to characterise the site only with relatively coarse resolution compared to the actual contaminant modelling needs. Adding also the need to take the environmental changes even within the current climate, e.g. land uplift, into consideration to this equation, a clear strategy and methodology to describe the biosphere development with relevant stages and resolution is necessary.

\section{OUTLINE OF THE METHODOLOGY}

Within compilation of the current three-year research and development programme for the disposal of nuclear waste in Finland [3], a step-wise approach to address the needs of biosphere description was drafted and preliminary studies started.

First of all, the development of landscape needs to be described with adequate resolution. In the case of the Olkiluoto site, this means mostly studying the shoreline displacement due to the land uplift and the changes in sea level. After that, utilising the overburden (i.e. soils and sediments) location and stratigraphy already surveyed, determination of possible vegetation types is seen possible as discussed below. For a complete description of a biosphere stage, also typical animal habitats and potential human activities need to be attached to the predicted vegetation patterns.

In the first version of this kind of descriptive model, planned to be used iteratively, focus will be on shoreline and wetland vegetation most probable to represent a current or former discharge area of deep groundwater, and on possible needs for further site characterisation. In the later versions more effort will be placed on the dryer areas, and possibly some targeted transect characterisation studies towards the inland can be implemented. 


\section{SHORELINE DISPLACEMENT AND OVERBURDEN TYPES}

In the Olkiluoto case the shoreline displacement, as mentioned above, comprises of isostatic land uplift and changes in sea level, further dependent on the global climate change. It is however quite straightforward to calculate the topographical projections, using the knowledge on the geological history and modern GIS software, and also to attach the stratigraphical information to them when one has the required site characterisation studies done in an adequate detail level, as is the situation in Olkiluoto (cf. [1]).

\section{STUDIES ON LAND UPLIFT SITES}

As a result of isostatic land uplift new land is becoming exposed to the combined effect of soil formation processes and other ecosystem processes that are controlled by the prevailing climate [5]. The primary stage of vegetation succession in new up-lifted soil is an open, early stage dominated by grasses and low-growing shrubs [6]. The succession of forest vegetation on stony, fine-textured till soils starts from alder-dominated (Alnus incana) deciduous shoreline vegetation, and ends in almost pure Norway spruce (Picea bies) stands which represent climax-like stage [6]. On gently sloping shores the succession series also includes a downy birch-dominated (Betula pubescens), intermediate stage [7]. The ecological change from the dinitrogen-fixing alder stage to the frequently paludified, nitrogen-deficient spruce stands with a thick humus layer is considerable [8].

According to Starr [5] the most typical soil type is a podzol after sufficient time and favourable conditions (i.e. Scots pine dominated forests on sandy soils with vertical drainage). Starr [5] observed a rapid podzolisation during the first 2,500 years but thereafter there was little further development.

In particular climatical and topographical conditions, vegetation succession turns to mire ecosystems (Fig. 2). Most of the peatlands in western Finland were initiated on land uplift shores [9-11]. The fresh soil surface, which emerged from water, was partly occupied by mire vegetation developing to brackish marshes. Primary mire formation was controlled by the shore displacement of the Baltic Sea. The land uplift also segregated bays, which developed to lakes. Part of them converted to peatlands filling-in and overgrown by mire vegetation. The primary mire formation and the overgrowth of water bodies were the starting points of larger mire areas, which reached their later scale by expanding over adjacent forests. Forest paludification took place especially during humid climatic periods and was promoted also by forest fires and storm damages.

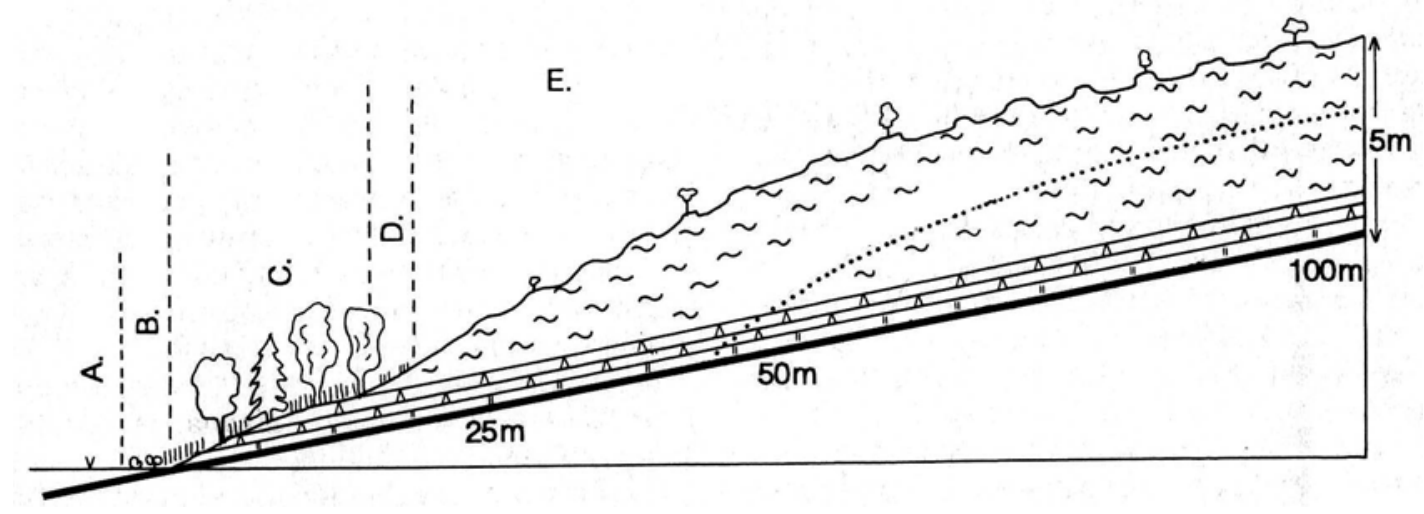

Figure 2. Mire succession from the shore to inland in the Satakunta region as described by Aario [5]. $\mathrm{A}=$ sea, $\mathrm{B}=$ =brackish marshes, $\mathrm{C}=$ minerotrophic treed and treeless mires, $\mathrm{D}=$ =transition mires, $\mathrm{E}=$ ombrotrophic bogs. Time scale is roughly 9,000 years - about the same as required to be assessed by the Finnish regulations. 
The general trend in the vegetation succession of these mires has been from minerotrophic sedge-dominated communities to ombrotrophic sphagnum-dominated communities [12-15]. This can be found out in several bogs in Satakunta region. Häädetkeidas bog in Parkano, $80 \mathrm{~km}$ east from coast and about $110 \mathrm{~km}$ northeast from the Olkiluoto site, was initiated on land uplift shore about 9,100 years ago. Transformation from minerotrophic mire to ombrotrophic bog takes about 2,000 years [16].

Numerous studies have been made in different forest or mire types developed from new up-lifted soil representing various stages of vegetation succession. Studies include among other things chemical, physical and biological characteristics of the soil, nutrient cycling and distribution in different ecosystem types as well as the effects of various vegetation communities on them. For example, a coastal chronosequence has offered an opportunity to study the inter-relationship between vegetational succession and the microbial processes that affect organic matter decomposition, nitrogen transformations, and thus nitrogen availability to plants [8].

\section{PREDICTING ANIMAL COLONISATION AND HUMAN ACTIVITIES}

After predictions on the vegetation type patterns at the different development stages, typical fauna can be estimated using the literature on the animal communities living in the current and past ecosystems - it is well known that certain species do not thrive on, or even habit at all, certain type of areas.

Same type of reasoning is valid also for predicting human activities. For example, in the temperate climate of Scandinavia, very stony soil is used for cultivation quite seldom if less stonier is available. Another, more evident example is that the nutrition conditions of soil dictate the type of food grown on the area, especially for self-sustaining communities. These factors can be described utilising an agriculture potential index to be further developed later on the basis of a review on the subject. Similar indices can be derived also for other types of activities, describing the probability of such types of potential exposure environments.

\section{DERIVATION OF BIOSPHERE MODELLING PARAMETERS}

Utilising the information on flora and fauna, as described in the biosphere development model, estimates on biomass and growth parameters for different relevant groups of species, affecting e.g. to the plant uptake, can be calculated with support from field measurements on now-existing sites. On the basis of ecological knowledge, food webs can be identified and pools and fluxes of main chemical entities approximated for each development stage described. These form a basis for ecologically based radionuclide transport and dose models, such as the carbon-14 model by Kumblad [17]. Further, the model parameter values can be partly assigned on the basis of field investigations and laboratory studies both with radionuclides and with stable elements analogical to the radionuclides of interest. The need for rather expensive experimental work is reduced significantly by using grouping of elements (and nuclides) e.g. on the basis of bioaccumulation or similar chemical behaviour in general - a method supported for at least the most of the radionuclides by a recent review by Greger [18].

\section{CONCLUSIONS}

An iterative step-wise methodology to describe the development stages of future biospheres on a land uplift site, specifically Olkiluoto, utilising the knowledge on other comparable uplift sites has been outlined on the basis of the regulations and guidance on the safety assessment of the planned spent nuclear fuel repository in Finland and other needs of the overall safety case planned to be compiled by end of 2012 with partial interim versions at earlier stages.

Describing the possible developments of such a diversiform system as site-scale biosphere has, of course, several endogenous difficulties. One of these is clearly the handling of various development paths including a myriad of details. Part of this problem is solved by scenario definitions of the overall safety assessment giving the big lines of the futures to be assessed. As with these larger-scale scenarios, also at the more detailed level of the biosphere development the large range of uncertainties 
and different development paths can be tackled with a mutually exclusive set of relatively few sub-scenarios or variants, covering all the range of relevant possibilities. After all, based on preliminary review, it can be seen that a site-specific biosphere development model described in this paper is feasible and can be further improved by some iteration together with radionuclide transport modelling.

\section{Acknowledgments}

The authors wish to thank SKB, the Swedish nuclear waste management organisation, and especially Ulrik Kautsky, on co-operation in biosphere research and modelling. The international BIOPROTA group is found a good venue for fruitful discussions; especially Paul Degnan and Mike Thorne have been helpful with refining the biosphere modelling strategy. Also Rodolfo Avila has presented, on several other occasions, good ideas developed into use.

\section{References}

[1] Baseline conditions at Olkiluoto, POSIVA-2003-02 (Posiva Oy, Olkiluoto, Finland, 2003) pp. 39-73.

[2] Long-term safety of disposal of spent nuclear fuel, Guide YVL 8.4 (Radiation and nuclear safety authority, Helsinki, 2001) pp. 3-4.

[3] TKS-2003; Nuclear waste management of the Olkiluoto and Loviisa power plants: Programme for research, development and technical design for 2004-2006 (Posiva Oy, Olkiluoto, Finland, 2003), pp. 249-52.

[4] Planning report for the safety assessment SR-Can, TR-03-08 (Svensk Kärnbränslehantering AB, Stockholm, 2003) pp. 73-82, 134-5.

[5] Starr, M.R. 1991. Soil formation and fertility along a 5000 year chronosequence. In: Pulkkinen, E. (ed.). Environmental geochemistry in northern Europe. Geological Survey of Finland, Special Paper 9: 99-104.

[6] Svensson, J.S. \& Jeglum, J.K. 2000. Primary succession and dynamics of Norway spruce coastal forests on land-uplift ground moraine. Studia Forestalia Suecica 209, 32 p.

[7] Svenonius, H. 1945. Gråalen som strandväxt vid Bottniska viken. Botaniska Notiser, 166-169.

[8] Merilä, P. 2002. Soil microbial dynamics and the condition of Norway spruce on the Bothnian land-uplift coast. Finnish Forest Research Institute, Research Papers 877, 55 p.

[9] Aario, L. 1932. Pflanzentopografische und paläogeographische Mooruntersuchungen in N-Satakunta. Fennia 55: 1-179.

[10] Brandt, A. 1948. Über die Entwicklung der Moore im Küstengebiet von Süd-Pohjanmaa am Bottnischen Meerbusen. Ann. Bot. Soc. Vanamo 23(4). 134 pp.

[11] Huikari, O. 1956. Primäärisen soistumisen osuudesta Suomen soiden synnyssä. Communicationes Instituti Forestalis Fenniae 46.6. 79 pp.

[12] Aartolahti, T. 1965. Oberflächenformen von Hochmooren und ihre Entwicklung in Südwest-Häme und Nord-Satakunta. Fennia 93: 1-268.

[13]Tolonen, K. 1967. Über die Entwicklung der Moore finnischen Nordkarelien. Ann. Bot. Fennici 4: 1-416.

[14] Elina, G. A. 1985. The history of vegetation in Eastern Karelia (USSR) during the Holocene. Aquilo Ser. Bot. 22: 1-36.

[15] Heikkilä, R., Kuznetsov, O., Lindholm, T., Aapala, K., Antipin, V., Djatshkova, T. \& Shevelin, P. 2001. Complexes, vegetation, flora and dynamics of Kauhaneva mire system, western Finland. The Finnish Environment 489. 97 pp.

[16] Damman, A.W.H., Tolonen, K. \& Sallantaus, T. 1994. Element retention and removal in ombrotrophic peat of Häädetkeidas, a boreal Finnish peat bog. Suo - Mires and peat 43(4-5) : 137-145.

[17] Kumblad, L. 2001. A transport and fate model of C-14 in a bay of the Baltic Sea at SFR: Today and in future, TR-01-15 (Svensk Kärnbränslehantering AB, Stockholm, 2001) 70 pp.

[18] Greger, M. 2004. Uptake of nuclides by plants, TR-04-14 (Svensk Kärnbränslehantering AB, Stockholm, 2001) 70 pp. 